\title{
ANALISIS TERHADAP FAKTOR YANG BERPENGARUH DALAM PENYUSUNAN LAPORAN PERTANGGUNGJAWABAN DI KABUPATEN SARMI PROVINSI PAPUA
}

\author{
Mardiana Dimo \\ dianaa.dimo@gmail.com
}

\begin{abstract}
Abstrak
The purpose of this study is to analyze the factors that influence the presentation of the Accountant Treasury Accountability Report. Three factors predicted to affect namely HR competency, education and training, and SIMDA implementation. The study conducted in Sarmi Regency, Papua Province, with a population of expenditure treasurers in 35 Regional Apparatus Organizations (OPD). The research sample of 70 people. The sampling method used is Purposive Sampling. The results of the study used Multiple Regression. The results of the study explained that partially HR competency factors had no significant effect, while the other two factors namely education and training, and SIMDA Implementation, had a positive impact. Simultaneously these three factors have a positive and significant effect.
\end{abstract}

Kata Kunci: pertanggungjawaban, bendahara pengeluaran, faktor berpengaruh

\section{PENDAHULUAN}

Fungsi seorang bendahara pengeluaran dalam mengelola keuangan daerah sangat penting. Kegiatan pengelolaan keuangan mempunyai kepentingan pengendalian terhadap pelaksanaan anggaran dan belanja daerah, karena adanya otorisasi yang telah diberikan melalui ketetapan dalam peraturan daerah dan pengesahannya oleh pejabat yang berwenang. Untuk itu perlu dievaluasi serangkaian pedoman tentang cara penatausahaan, penyusunan laporan, dan pertanggungjawaban bendahara serta penyampaiannya Safwan \& Abdullah (2014).

Sehubungan dengan kegiatan pertanggungjawaban penggunaan dana di OPD, dalam Pasal 220 ayat (10) Permendagri 13/2006 diatur hal sebagai berikut: "Bendahara pengeluaran pada OPD wajib mempertanggung jawabkan secara fungsional atas pengelolaan uang yang menjadi tanggung jawabnya dengan menyampaikan laporan pertanggungjawaban pengeluaran kepada PPKD selaku BUD paling lambat tanggal 10 bulan berikutnya."

Fenomena penyampaian laporan pertanggungjawaban oleh bendahara pengeluaran sampai saat ini di Kabupaten Sarmi masih memprihatinkan (Salle, lek, \& Hafizrianda, 2015). 
Satuan Kerja Perangkat Daerah yang berada masih bermasalah karena tidak tepat waktu dalam penyampaian laporan pertanggungjawaban. Seharusnya seorang bendahara harus memahami mengenai tugas pokok, tanggung jawab, uraian pekerjaan, dan fungsi bendahara itu sendiri. Seperti diatur dalam Peraturan Pemerintah Nomor 55 tahun 2008 tentang Tata Cara Penatausahaan dan Penyusunan Laporan Pertanggungjawaban Bendahara Serta Penyampaiannya, dengan jelas disebutkan bahwa bendahara pengeluaran mempertanggungjawabkan pengelolaan uang yang menjadi tanggung jawabnya kepada PPKD paling lambat tanggal 10 bulan berikutnya. Karena pertanggung jawaban tersebut, merupakan bentuk dari akuntabilitas seorang pengelola keuangan dalam menjalankan tugas dan tanggug jawabnya.

Realita menunjukan pendidikan dan pelatihan memiliki peran strategis untuk meningkatkan kualitas sumber daya aparatur yaitu aparatur pegawai yang profesional baik dalam hal kompetensi, sikap dan perilaku yang diharapkan sesuai dengan tugas dan peranannya masing-masing. Permasalahan yang sering muncul dalam penyelenggaraan diklat adalah masalah kompetensi lulusan peserta diklat yang tidak sesuai dengan pelaksanaan tugas dan fungsi dalam jabatannya. Hal ini disebabkan lulusan diklat memiliki kreativitas yang rendah, pengetahuan dan keterampilan yang dimiliki tidak mampu mengatasi tantangan zaman serta tidak mampu memanfaatkan peluang yang ada.

Laporan pertanggungajawaban bendahara merupakan salah satu perwujudan kinerja Bendahara pengeluaran yang berperan dalam akuntabilitas kinerja instansi. LAN dan BPKP (2000) menyebutkan, dalam pelaksanaan akuntabilitas ini, diperlukan pula perhatian dan komitmen yang kuat dari atasan langsung instansi memberikan akuntabilitasnya, untuk mengevaluasi akuntabilitas kinerja bendahara instansi tersebut.

Melihat kondisi tersebut, Pemda harus mempunyai langkah-langkah taktis dan strategis untuk membenahi manajemen keuangan di tingkat daerahnya salah satunya adalah dengan memaksimalkan peran dari aparatur yang terlibat dalam proses pengelolaan keuangan dalam hal ini adalah bendahara pengeluaran dan PPK-OPD. Untuk mendorong dan memacu perannya dalam sebuah status sebagai bendahara pengeluaran dan PPK- 
OPD. Meskipun masing-masing mempunyai peran dengan tugas dan fungsi yang berbeda tetapi saling melengkapi dalam rangka mewujudkan pengelolaan keuangan yang baik dalam lingkungan satuan kerjanya.

Dalam penatausahaan, Bendahara pengeluaran bertugas untuk menerima, menyimpan, membayar, menatausahakan, dan mempertanggungjawabkan uang untuk keperluan belanja daerah dalam rangka pelaksanaan APBD pada OPD. Hal-hal yang dilakukan oleh bendahara pengeluaran adalah pengajuan surat permintaan pembayaran UP/GU/TU, pembukuan penerimaan SP2D UP/GU/TU/LS, pembukuan menggunakan uang persediaan, pembukuan pertanggungjawaban uang panjar, dan pembukuan pertanggungjawaban tambah uang. Dokumen yang digunakan antara lain salinan SPD, draft surat pernyataan pengguna anggaran, SP2D, bukti transaksi, LPJ penggunaan UP/TU, dan dokumen pelengkap lainnya. Pencatatan dilakukan pada buku kas umum dan buku-buku pembantu Wokas, Poputra, \& Sugeha (2015)

Pertanggungjawaban merupakan hal penting dalam pengelolaan keuangan daerah. Karena dalam penggunaan anggaran, harus dapat dipertanggungjawabkan pemakaiannya. Hubungan administrasi keuangan dengan proses pertanggungjawaban bendahara pengeluaran adalah kegiatan pengelolaan keuangan yang dilakukan pemerintah melalui tata usaha keuangan yang dilakukan secara sistematis di bidang keuangan berdasarkan prosedur-prosedur tertentu yang dilakukan melalui proses kegiatan kerjasama sehingga proses pertanggungjawaban bendahara pengeluaran dapat berjalan dengan baikRahmatiah (2016).

Latar belakang pendidikan merupakan salah satu penunjang pegawai untuk dapat menyelesaikan suatu pekerjaan, melalui pendidikan yang semakin tinggi pegawai diharapkan mempunyai pengetahuan yang lebih baik sehingga mampu serta cakap untuk melaksanakan tugasnya dengan baik. Latar belakang pendidikan menjadi faktor penunjang mencapai kinerja bendahara karena tingginya tingkat pendidikan akan membantu bendahara dapat menyerap informasi yang berhubungan dengan pengelolaan keuangan. Kesesuaian latar belakang pendidikan yang dimiliki oleh bendahara akan dapat meningkatkan kinerja individu, 
dan dapat berdampak pada peningkatan kinerja organisasi Wasasih, Yadnyana, \& Rasmini (2016).

Faktor lain yang memengaruhi pertanggungjawaban bendahara pengeluaran adalah pelatihan tentang pengelolaan keuangan. Pelatihan merupakan proses belajar mengajar dengan menggunakan teknik dan metode tertentu. Secara konsepsional pelatihan dimaksudkan untuk meningkatkan ketrampilan dan kemampuan kerja bendahara. Pelatihan mengacu pada upaya yang direncanakan oleh suatu organisasi untuk mempermudah pembelajaran para pegawai tentang kompetensi-kompetensi yang dibutuhkan dalam penyelesaian suatu pekerjaan. Variabel lain yang memengaruhi kinerja pegawai adalah motivasi yakni suatu proses yang menghasilkan suatu intensitas, arah, dan ketekunan individual dalam usaha untuk mencapai suatu tujuan Robbins dan Judge (2008) Motivasi yang ada dalam diri pegawai ikut menentukan hasil kerja pegawai tersebut. Oleh karena itu, perusahaan harus senantiasa berusaha untuk mempertahankan dan bahkan meningkatkan motivasi yang ada dalam diri pegawainya Soeharto (2005).

Kenyataan permasalahan dalam hal pertanggungjawaban penggunaan dana yang berasal dari OPD atau yang lebih dikenal dengan istilah surat pertanggungjawaban (SPJ) tidak dapat dipandang sebelah mata. Hal ini mengingat karena dalam kegiatan penyusunan laporan keuangan pemerintah daerah, ketidaktepatan surat pertanggungjawaban (SPJ) dari satuan kerja perangkat daerah (OPD) menjadi hal yang crusial, karena SPJ merupakan salah satu wujud bukti transaksi pengeluaran yang dibutuhkan dalam rangka penyelenggaraan sistem akuntansi keuangan daerah, yang antara lain diimplementasikan dalam penyusunan laporan keuangan tahunan pemerintah daerah, yang terdiri dari laporan realisasi anggaran (LRA), neraca, arus kas, dan catatan atas laporan keuangan (CaLK) Nilawati (2009).

Masalah yang menjadi perhatian peneliti ialah menganalisis peran faktor SDM, pendidikan dan pelatihan, implementasi SIMDA berpengaruh terhadap penyajian pertanggungjawaban bendahara pengeluaran. 


\section{LANDASAN TEORI DAN PENGEMBANGAN HIPOTESIS}

Teori Keagenan (Agency Theory)

Teori keagenan atau teori prinsipel-agen adalah teori yang menjelaskan hubungan antara pihak pemberi dengan pihak penerima hak dan kewajiban, yang diikat dengan perjanjian atau kontrak. Pihak pemberi hak dan kewajiban disebut prinsipal, sedang pihak penerima hak dan kewajiban disebut agen. Pada perjalanannya, agen memiliki keleluasaan dengan adanya asimetri informasi, sehingga dapat melakukan kegiatan yang mengakibatkan dirinya mendapatkan hak lebih besar dari yang sewajarnya, hal inilah yang mendasari perilaku oportunistik atau perilaku yang bertujuan untuk memenuhi kepentingan salah satu pihak tertentu.

Teori keagenan juga dapat menjelaskan hubungan para pihak dalam sector pemerintahan, legislatif sebagai prinsipal dan eksekutif sebagai agen. Hubungan ini dapat menyebabkan perilaku oportunistik bagi eksekutif mengingat eksekutif sebagai perancang anggaran sekaligus sebagai pelaksana anggaran. Menurut Brower, Abolafia, \& Carr (2000), model keagenan yang sederhana mengasumsikan dua pilihan dalam kontrak (1) behaviorbased, yakni prinsipal harus memonitor perilaku agen dan (2) outcome-based, yakni adanya insentif untuk memotivasi agen dalam mencapai kepentingan prinsipal. Oportunisme bermakna bahwa ketika terjalin kerjasama antara prinsipal dan agen, kerugian prinsipal karena agen mengutamakan kepentingannya (agent self-interest) kemungkinan besar akan terjadi. Praktik agen yang mengutamakan kepentingannya akan berdampak pada pengelolaan keuangan dan laporan keuangan yang menyimpang dari peraturan perundangan-undangan maupun standar akuntansi yang berlaku, sehingga hasil pemeriksaan laporan keuangan akan mendapat opini selain Wajar Tanpa Pengecualian (WTP).

\section{Ketepatan waktu pelaporan}

Pertanggungjawaban atas uang/kas yang ada di Satuan Kerja Perangkat Daerah dilakukan oleh bendahara pengeluaran selaku pejabat fungsional (Pasal 14 Permendagri 13/2006) keperbendaharaan, artinya selain membuat Pertanggungjawaban administratif 
kepada kepala Satuan Kerja Perangkat Daerah, bendahara juga menyampaikan pertanggungjawaban fungsional kepada Bendahara Umum Daerah (BUD). Hal ini sejalan dengan yang dinyatakan dalam UU 1/2004 tentang perbendaharaan bahwa bendahara bertanggungjawab secara pribadi atas seluruh pengeluaran yang dilakukannya.

Menurut Peraturan Menteri Dalam Negeri tentang perubahan kedua atas peraturan Menteri Dalam Negeri No. 13 Tahun 2006 tentang Pedoman Pengelolaan Keuangan Daerah Pasal 1 Ayat 24, mengatakan bahwa Bendahara Pengeluaran adalah pejabat fungsional yang ditunjuk menerima, menyimpan, membayarkan, menatausahakan, dan mempertanggungjawabkan uang untuk keperluan belanja daerah dalam rangka pelaksanaan APBD pada OPD. Penatausahaan pengeluaran daerah pada tingkat OPD dilaksanakan oleh Pengguna Anggaran/Kuasa Pengguna Anggaran, Pejabat Penatausahaan Keuangan Satuan Kerja Perangkat Daerah (PPK-OPD), Pejabat Pelaksana Teknis Kegiatan (PPTK), dan Bendahara Pengeluaran, serta Bendahara Pengeluaran Pembantu jika diperlukan.

Penatausahaan pengeluaran daerah pada tingkat OPD dilakukan oleh Pejabat Pengelola Keuangan Daerah selaku BUD dan Kuasa BUD. Permana (2013) menjelaskan dalam melakukan penatausahaan pertanggungjawaban yang dilakukan bendahara pengeluaran sejalan dengan uraian Prosedur yang diatur dalam Peraturan Bupati Nomor 26 Tahun 2014, tentang Sistem dan prosedur Pengelolaan Keuangan Daerah Kabupaten Serdang Bedagai. Bendahara Pengeluaran secara fungsional dan administrative wajib mempertanggungjawabkan penggunaan UP/GU/TU dan LS kepada kepala OPD melalui PPK-OPD paling lambat tanggal 10 bulan berikutnya, pada bulan terakhir tahun anggaran paling lambat hari kerja terakhir bulan tersebut, pertanggungjawaban tersebut dilampiri bukti setoran sisa uang persediaan Permana (2013)

Penempatan Sumber Daya Manusia ( SDM )

Azhar (2016) menjelaskan bahwa "Sumberdaya Manusia merupakan pilar penyangga utama sekaligus penggerak roda organisasi dalam usaha mewujudkan visi dan misi serta tujuan dari organisasi tersebut". Sumber daya manusia merupakan elemen organisasi yang sangat penting, karena harus di pastikan sumberdaya manusia harus dikelola sebaik 
mungkin agar mampu memberikan kontribusi secara optimal dalam upaya pencapaian tujuan organisasi. Menurut Hadiputro (2015) Sumber Daya Manusia adalah kesatuan tenaga manusia yang ada dalam suatu organisasi dan bukan sekedar penjumlahan karyawankaryawan yang ada. Sebagian kesatuan sumber daya manusia harus dipandang sebagai suatu sistem dimana tiap-tiap karyawan merupakan bagian yang saling berkaitan satu dengan lainnya dan bersama-sama berfungsi untuk mencapai tujuan organisasi.

Dalam rangka pengelolaan keuangan daerah yang baik, OPD harus memiliki kualitas SDM yang di dukung dengan latar belakang pendidikan akuntansi, sering mengikuti pendidikan dan pelatihan, dan mempunyai pengalaman di bidang keuangan karena permasalahannya adalah untuk menerapkan akuntansi double entry berbasis akrual di perlukan sumber daya manusia yang memahami logika akuntansi secara baik. Aparatur pemda yang menangani masalah keuangan tidak cukup hanya menguasai penatausahaan anggaran melainkan juga harus memahami karakteristik transaksi yang terjadi dan pengaruhnya terhadap rekening - rekening dalam laporan keuangan yang di buat dan ketidaksesuaian laporan dengan standar yang di tetapkan pemerintah.

Meliani (2018) menyatakan kompetensi diartikan sebagai kemampuan untuk melaksanakan atau melakukan suatu pekerjaan atau tugas yang dilandasi oleh keterampilan dan pengetahuan kerja yang dituntut oleh pekerjaan tersebut. Dengan demikian, kompetensi menunjukkan keterampilan atau pengetahuan yang dicirikan oleh profesionalisme dalam suatu bidang tertentu sebagai suatu yang terpenting. Kompetensi sebagai karakteristik seseorang berhubungan dengan kinerja yang efektif dalam suatu pekerjaan atau situasi. Kravetz (2004) juga mengemukakan kompetensi adalah sesuatu yang seseorang tunjukkan dalam kerja setiap hari. Fokusnya adalah pada perilaku di tempat kerja, bukan sifat-sifat kepribadian atau ketrampilan dasar yang ada di luar tempat kerja ataupun di dalam tempat kerja.

\section{Pendidikan dan Pelatihan}

Pasal 1 Undang-Undang Republik Indonesia Nomor 20 Tahun 2003 tentang Pendidikan Nasional menyatakan bahwa pendidikan adalah usaha sadar dan terencana 
untuk mewujudkan suasana belajar dan proses pembelajaran agar peserta didik secara aktif mengembangkan potensi dirinya untuk memiliki kekuatan spiritual keagamaan, pengendalian diri, kepribadian, kecerdasan, akhlak mulia, serta keterampilan yang diperlukan dirinya, masyarakat, bangsa dan negara.

Siagian (2011) menyatakan bahwa setiap orang ingin mengembangkan kemampuannya sehingga potensi yang dimilikinya berubah menjadi kemampuan efektif. Salah satu cara untuk mengubah potensi seseorang menjadi kemampuan nyata ialah melalui pendidikan. Pendidikan sering diartikan sebagai usaha manusia untuk membina kepribadiannya sesuai dengan nilai-nilai di dalam masyarakat dan kebudayaan. Selanjutnya, pendidikan diartikan sebagai usaha yang dijalankan oleh seseorang atau kelompok orang lain agar menjadi dewasa atau mencapai tingkat hidup atau penghidupan yang lebih tinggi dalam arti mental Hasbullah (2008).

Mangkunegara \& Prabu (2003) menyatakan bahwa tingkat pendidikan adalah suatu proses jangka panjang yang menggunakan prosedur sistematis dan terorganisir, yang mana tenaga kerja manajerial mempelajari pemahaman konseptual dan teoritis untuk tujuan-tujuan umum. Demikian pula Hariandja (2002) menyatakan bahwa tingkat pendidikan seorang karyawan dapat meningkatkan daya saing perusahaan dan memperbaiki produktivitas perusahaan. Melalui pendidikan seseorang dipersiapkan untuk memiliki bekal agar siap tahu, mengenal dan mengembangkan metode berpikir secara sistematik agar dapat memecahkan masalah yang akan dihadapi dalam kehidupan di kemudian hari Sedarmayanti (2003). Pendidikan yang berkualitas dapat mengembangkan potensi dan keterampilan yang diperlukan individu, masyarakat, bangsa dan negara.

Pelatihan menurut Dessler (2011) merupakan proses membantu para tenaga kerja untuk memperoleh efektivitas dalam pekerjaan mereka yang sekarang atau yang akan datang melalui pengembangan kebiasaan tentang pikiran, tindakan, kecakapan, pengetahuan, dan sikap yang layak. Pelatihan merupakan salah satu usaha organisasi yang sengaja dilakukan untuk meningkatkan kinerja pegawai. Moekijat (2002) menyatakan bahwa pelatihan harus bisa membantu pegawai menambah pengetahuannya dalam menjalankan 
tugasnya serta mampu menimbulkan perubahan kebiasaan dan sikap yang diterapkan dalam tugas.

\section{Faktor Sistem Informasi Manajemen Daerah}

Dewasa ini, perkembangan teknologi informasi komunikasi yang semakin pesat telah mempengaruhi sistem pengolahan data dan sistem informasi pada entitas yang melakukan pelaporan data keuangan. Untuk dapat melakukan pengolahan data keuangan secara efektif dan efisien maka dibutuhkan suatu sistem informasi terintegrasi yang dapat diandalkan, cepat dan akurat sehingga suatu sistem dapat diintegrasikan secara menyeluruh dan mampu memberikan informasi yang handal dan relevan.

Sistem informasi merupakan kebutuhan bagi suatu entitas dalam menjalankan aktivitasnya. Kelangsungan hidup organisasi sangatlah sulit tanpa penggunaan teknologi sistem informasi. Sistem informasi menjadi penting dalam membantu organisasi menghadapi pesatnya arus ekonomi global. Menurut Loudon (2008) sistem informasi dibangun oleh manajer untuk melayani kepentingan perusahaan. Pada saat bersamaan, organisasi harus waspada dan terbuka terhadap pengaruh sistem informasi untuk mendapatkan manfaat dari teknologi baru. Sistem informasi menjadi vital untuk menjalankan bisnis harian serta mencapai tujuan bisnis dan tujuan strategi.

Sama halnya dengan kebutuhan sistem informasi di sektor swasta, di sektor pemerintahan kebutuhan sistem informasi dalam penyelenggaraan pemerintahan serta sasaran-sasaran yang akan dicapai sudah mulai menggunakan sistem informasi berbasis komputer (computer based information system) tak terkecuali dalam hal pengelolaan keuangan. Oleh sebab itu, kegiatan pengendalian berupa pengelolaan sistem informasi adalah suatu kegiatan yang harus dilakukan demi menjamin suatu aplikasi sistem informasi yang digunakan oleh Instansi Pemerintah sebagai alat bantu pengelolaan keuangan dapat memberikan jaminan pengendalian intern yang memadai.

Secara umum, Sistem Informasi Manajemen (SIM) merupakan suatu sistem yang dapat membantu manajemen di dalam pengumpulan data, pengolahan serta analisis evaluasi data dan menyajikan ke dalam batas informasi yang bernilaidan akhirnya sampai 
pada pengambilan keputusan di mana informasi ini berguna untuk mendukung fungsi operasi manajemen Machmud (2013). Tujuan dari pelaporan keuangan sektor publik adalah Bastian (2010: 297) menyediakan informasi mengenai sumber daya, alokasi, dan penggunaan sumber daya keuangan, menyediakan informasi mengenai bagaimana entitas mendanai aktivitasnya dan memenuhi kebutuhan kasnya, menyediakan informasi yang berguna untuk mengevaluasi kemampuan entitas dalam membiayai aktivitasnya dan memenuhi kewajiban serta komitmennya, menyediakan informasi mengenai kondisi keuangan suatu entitas dan perubahan yang terjadi, dan menyediakan informasi secara keseluruhan yang berguna dalam mengevaluasi kinerja entitas menyangkut biaya jasa, efisiensi, dan pencapaian tujuan. Guna mewujudkan praktik pengelolaan keuangan daerah yang cepat, tepat, dan akurat, Badan Pengawas Keuangan dan Pembangunan (BPKP) telah mengembangkan sistem aplikasi komputer yang dapat mengolah data transaksi keuangan menjadi laporan keuangan yang dapat dimanfaatkan setiap saat, yakni Sistem Informasi Manajemen Daerah sebuah sistem berbasis aplikasi teknologi yang dikembangkan untuk mendukung tercapainya akuntabilitas bagi pemerintah daerah baik ditingkat pelaporan (SKPKD) ataupun ditingkat akuntansi (OPD). Dharma (2015) Aplikasi ini diharapkan dapat membantu pemerintah daerah dalam penyusunan perencanaan dan penganggaran, serta pelaksanaan dan penatausahaan APBD dan pertanggungjawaban APBD (www.BPKP.go.id).

Aplikasi Sistem Informasi Manajemen Daerah yang dikembangkan oleh Badan Pengawasan Keuangan dan Pembangunan (BPKP) dan dikenal dengan Aplikasi Sistem Informasi Manajemen Daerah merupakan salah satu produk dari teknologi sistem informasi yang digunakan oleh banyak pemerintah daerah di Indonesia dalam menyelenggarakan pengelolaan keuangan daerahnya. Madukala, Nasrul, \& Mahrani (2018) mendefiniskan Aplikasi Sistem Informasi Manajemen Daerah sebagai Aplikasi Sistem Informasi Manajemen Daerah adalah aplikasi Sistem Informasi Manajemen Daerah yang dikembangkan oleh Badan Pengawasan Keuangan dan Pembangunan (BPKP), dimana tujuan dari pengembangan aplikasi ini adalah untuk mempercepat proses reformasi pengelolaan keuangan daerah. Hal ini dilatarbelakangi oleh langkanya sumber daya manusia di 
pemerintahan daerah yang memiliki latarbelakang akuntansi, sehingga pemerintah daerah mengalami kesulitan dalam menyusun laporan keuangan sesuai dengan peraturan perundang-undangan yang berlaku MenurutMadukala et al (2018) Apliksi Sistem Informasi Manajemen Daerah Sistem Informasi Manajemen Daerah merupakan suatu program yang dikembangkan dengan menggunkan database. Database menurut Laudon (2007) merupakan sekumpulan data organisasi untuk melayani banyak aplikasi secara efisien dengan memusatkan dan mengendalikan data.

Aplikasi Sistem Informasi Manajemen Daerah telah terintegrasi mulai dari fungsi penganggaran, fungsi penatausahaan keuangan daerah, sampai fungsi akuntansi dan pelaporan. Maka dalam setiap implementasi suatu sistem berbasis komputer, perlu ditunjuk pihak yang berperan sebagai administrator. Administrator mempunyai fungsi untuk mengelola database, mengelola aplikasi (sotfware) dan hardware. Pada masing-masing OPD yang menjadi administrator adalah Pengguna Anggaran, Pejabat Penatausahaan Keuangan (PPK), Bendahara Pengeluaran, dan Pejabat Pengelola Teknis Kegiatan (PPTK) sebagai pengguna akhir (end users) dari Aplikasi Sistem Informasi Manajemen Daerah.

Hipotesis Penelitian

\section{Faktor kompetensi SDM}

Menurut teori keagenan oleh Teori Magner \& Johnson (1995) prinsipal agen menjelaskan bahwa pihak-pihak yang terlibat dalam proses penyusunan anggaran memiliki kecenderungan untuk memaksimalkan utilitasnya melalui pengalokasian sumberdaya dalam anggaran yang ditetapkan. Variabel sumber daya manusia merupakan faktor yang berperan terhadap proses ketepatan penyampaian laporan pertanggungjawaban, Semakin bagus sumberdaya manusia yang ada pada pemerintah daerah maka semakin baik pula ketepatan waktu penyampaian laporan keuangan. Hal ini didukung oleh beberapa riset diantaranya oleh Rasdianto (2014), Nilawati (2009) dan Wibowo (2013). Semakin tinggi tingkat sumber daya manusia bendahara maka semakin paham dalam penyusunan pertanggungjawaban dan semakin tepat proses penyampaian laporan pertanggungjawaban yang dibutuhkan. Berdasarkan uraian diatas, hipotesis penelitian yang diajukan dalam penelitian ini: 
H1: Kompetensi SDM berpengaruh positif terhadap ketepatan waktu penyampaian laporan pertanggungjawaban. bendahara pengeluaran.

\section{Faktor pendidikan dan pelatihan}

Teori keagenan yang menjelaskan hubungan prinsipal dan agen berakar pada teori ekonomi, teori keputusan, sosiologi, dan teori organisasi. Teori keagenan menganalisis susunan kontraktual di antara dua atau lebih individu, kelompok, atau organisasi. Salah satu pihak (principal) membuat suatu kontrak, baik secara implisit maupun eksplisit, dengan pihak lain (agent) dengan harapan bahwa agen akan bertindak/melakukan pekerjaan seperti yang diinginkan oleh prinsipal. Lupia \& McCubbins (2000) menyatakan: delegation occurs when one person or group, a principal, select another person or group, an agent, to act on the principal's behalf. Menurut Wedemeyer \& Ross (1973) contoh-contoh hubungan keagenan sangat universal.

PenelitianWasasih et al (2016) hasil penelitian menunjukan pendidikan berpengaruh positif signifikan pada kinerja bendahara OPD Kabupaten Tabanan. Pelatihan mampu memperkuat pengaruh pendidikan pada kinerja bendahara OPD Kabupaten Tabanan. Semakin banyak pelatihan yang diikuti, maka kinerja bendahara OPD Kabupaten Tabanan. Berdasarkan uraian diatas, hipotesis penelitian yang diajukan dalam penelitian ini:

H2: Pendidikan dan pelatijan berpengaruh positif terhadap ketepatan waktu penyampaian laporan pertanggungjawaban. bendahara pengeluaran.

Faktor sistem informasi manajemen daerah (SIMDA)

Teori keagenan memprediksi bahwa perusahaan dengan rasio leverage yang lebih tinggi akan mengungkapkan lebih banyak informasi, karena biaya keagenan perusahaan dengan struktur modal seperti itu lebih tinggi Jensen \& Meckling, (1976: 354) Tambahan informasi diperlukan untuk menghilangkan keraguan pemegang obligasi terhadap dipenuhinya hak-hak mereka sebagai kreditur [Schipper dalam Marwata (2001:18) dan (Varejão, Meek, Ferreira, Patrício, \& Cabrita, 2001) Oleh karena itu perusahaan dengan rasio leverage yang tinggi memiliki kewajiban untuk melakukan ungkapan yang lebih luas 
daripada perusahaan dengan rasio leverage yang rendah. Signalling theory menekankan kepada pentingnya informasi yang dikeluarkan oleh perusahaan terhadap keputusan investasi pihak di luar perusahaan. Informasi merupakan unsur penting bagi investor dan pelaku bisnis karena informasi pada hakekatnya menyajikan keterangan, catatan atau gambaran baik untuk keadaan masa lalu, saat ini maupun keadaan masa yang akan datang bagi kelangsungan hidup suatu perusahaan dan bagaimana pasaran efeknya. Informasi yang lengkap, relevan, akurat dan tepat waktu sangat diperlukan oleh investor di pasar modal sebagai alat analisis untuk mengambil keputusan investasi.

Djadja (2009) mendefiniskan Aplikasi Sistem Informasi Manajemen Daerah sebagai Aplikasi Sistem Informasi Manajemen Daerah adalah aplikasi yang dikembangkan oleh Badan Pengawasan Keuangan dan Pembangunan (BPKP), dimana tujuan dari pengembangan aplikasi ini adalah untuk mempercepat proses reformasi pengelolaan keuangan daerah. Hal ini dilatarbelakangi oleh langkanya sumber daya manusia di pemerintahan daerah yang memiliki latarbelakang akuntansi, sehingga pemerintah daerah mengalami kesulitan dalam menyusun laporan keuangan sesuai dengan peraturan perundangundangan yang berlaku Menurut Djadja (2009) Apliksi Sistem Informasi Manajemen Daerah merupakan suatu program yang dikembangkan dengan menggunakan database. Database menurutNilsson et al. (2008) merupakan sekumpulan data organisasi untuk melayani banyak aplikasi secara efisien dengan memusatkan dan mengendalikan data.Trihapsoro \& Setiawati (2015) menyimpulkan bahwa pemanfaatan teknologi informasi berpengaruh signifikan terhadap kinerja pemerintah daerah. Berdasarkan uraian diatas, di duga variabel. Berdasarkan uraian diatas, hipotesis penelitian yang diajukan dalam penelitian ini:

H3: Sistem informasi manajemen daerah berpengaruh positif terhadap ketepatan waktu penyampaian laporan pertanggungjawaban bendahara pengeluaran pendidikan dan pelatihan berpengaruh positif terhadap ketepatan. 


\section{METODE PENELITIAN}

Penelitian ini digolongkan sebagai penelitian penjelasan (eksplanatory) karena berupaya untuk menjelaskan pertanggungjawaban Bendahara Pengeluaran. Pendekatan dalam penelitian ini termasuk dalam penelitian kuantitatif, model penelitiannya adalah model survei dengan menggunakan instrument kuesioner dengan maksud untuk mendapatkan data opini individu responden Jogiyanto (2008) serta dilakukan pengujian hipotesis.

Adapun yang menjadi sampel sesuai dengan kriteria sebagai berikut: (1) pegawai negeri sipil pada organisasi perangkat daerah (OPD) Pemerintah Kabupaten Sarmi, (2) pegawai yang telah bekerja sebagai bendahara pengeluaran minimal 1 (satu) tahun pada Satuan Kerja Perangkat Daerah. Jumlah responden ada 70 orang.

Data yang digunakan dalam penelitian ini meliputi dua jenis yaitu data primer dan data sekunder. Data primer dihimpun melalui survai yang menggunakan kuesioner. Kuesioner diisi melalui saat melakukan wawancara langsung dengan responden. Data sekunder dihimpan dari Pemerintah Kabupaten Sarmi berupa laporan Bendahara Pengeluaran, dan data BPS.

Menurut Sugiyono (2005) analisis regresi berganda digunakan oleh peneliti, bila peneliti bermaksud meramalkan bagaimana keadaan (naik turunnya) variabel dependen, bila dua atau lebih variabel independen sebagai faktor prediktor dimanipulasi (dinaik turunkan nilainya). Metode ini digunakan untuk mengetahui variabel yang dominan memberi sumbangan terhadap variabel terikat dan untuk mengetahui pengaruh antara dua variabel atau lebih, yaitu variabel bebas dan variabel terikat. Rumusnya (unstandardized coefficients) adalah:

$Y=a+b 1 X 1+b 2 X 2+b 3 X 3+\varepsilon$

Keterangan;

$\mathrm{Y}=$ Penyajian laporan pertanggunjawaban bendahara pengeluaran

$\alpha=$ Intercept

$\mathrm{b}=$ Koefisien regresi

$\mathrm{X} 1=$ Kompetensi SDM

X2 = Pendidikan dan Pelatihan 
$\mathrm{X} 2=$ Implementasi Simda

$\varepsilon \quad=$ residual

\section{HASIL PENELITIAN DAN PEMBAHASAN}

Jumlah responden yang dihubungi untuk mengisi kuesioner sebanyak 70 orang (70 kuesioner). Dari jumlah ini sebanyak 47 kuesioner (67\%) yang dapat diolah. Dari jumlah responden yang mengembalikan kuesioner 21 orang (45\%) berpendidikan sekolah menengah. Sarjana 14 orang (30\%), dan pasca sarjana 3 orang $(6 \%)$.

\section{Distribusi Frekuensi Jawaban Responden Tentang Kompetensi SDM}

Berikut ini adalah deskripsi jawaban responden mengenai pencarian variabel kompetensi SDM:

Tabel 1

Rekapitulasi Distribusi Frekuensi Variabel Kompetensi SDM

\begin{tabular}{|c|c|c|c|c|c|c|c|c|c|c|c|c|c|}
\hline \multirow{3}{*}{ Item } & \multicolumn{12}{|c|}{ Frekuensi Jawaban } & \multirow{3}{*}{$\begin{array}{c}\text { Rata-rata } \\
\%\end{array}$} \\
\hline & 5 & \multirow{2}{*}{$\%$} & 4 & \multirow{2}{*}{$\%$} & 3 & \multirow{2}{*}{$\%$} & 2 & \multirow{2}{*}{$\%$} & 1 & & \multicolumn{2}{|c|}{ Total } & \\
\hline & SS & & $\mathbf{S}$ & & $\mathbf{N}$ & & TS & & STS & $\%$ & $\bar{F}$ & $\%$ & \\
\hline$X_{1.1}$ & 18 & 38,3 & 17 & 36,2 & 6 & 12.8 & 4 & 8.5 & 2 & 4.3 & 47 & 100 & 3,96 \\
\hline$X_{1.2}$ & 18 & 38,3 & 22 & 46.8 & 1 & 2.1 & 4 & 10.6 & 1 & 2,1 & 47 & 100 & 4,09 \\
\hline$X_{1.3}$ & 17 & 36.2 & 19 & 40.4 & 6 & 12.8 & 4 & 8.5 & 1 & 2,1 & 47 & 100 & 4,00 \\
\hline \multicolumn{13}{|c|}{ Rata-rata Kompetensi SDM } & 4,01 \\
\hline
\end{tabular}

Sumber : Data diolah

Hasil analisis pada Tabel 1 tentang jawaban responden tentang variabel kompetensi SDM yang diukur melalui 3 pernyataan, dengan nilai rata-rata sebesar 4,01\% menunjukkan bahwa variabel ini mampu dijelaskan dengan baik oleh pernyataan-pernyataan di atas. Pernyataan yang relatif lebih baik dalam menjelaskan variabel ini adalah pernyataan pertama $\left(\mathrm{X}_{1 \cdot 2}\right)$, yaitu pembantu bendahara dan bendahara pembantu tersebut telah melaksanakan tugas yang menjadi tanggungjawab dengan baik.

\section{Distribusi Frekuensi Jawaban Responden Tentang Pendidikan dan Pelatihan}

Berikut ini adalah deskripsi jawaban responden mengenai pencarian variabel pendidikan dan pelatihan: 
Tabel 2

Rekapitulasi Distribusi Frekuensi Variabel pendidikan dan pelatihan

\begin{tabular}{|c|c|c|c|c|c|c|c|c|c|c|c|c|c|}
\hline \multirow{3}{*}{ Item } & \multicolumn{12}{|c|}{ Frekuensi Jawaban } & \multirow{3}{*}{$\begin{array}{c}\text { Rata-rata } \\
\%\end{array}$} \\
\hline & 5 & \multirow{2}{*}{$\%$} & 4 & \multirow{2}{*}{$\%$} & 3 & \multirow{2}{*}{$\%$} & 2 & \multirow{2}{*}{$\%$} & 1 & 0 & \multicolumn{2}{|c|}{ Total } & \\
\hline & SS & & $S$ & & $\mathrm{~N}$ & & TS & & STS & $\%$ & $F$ & $\%$ & \\
\hline$X_{2.1}$ & 19 & 40,4 & 18 & 38,3 & 4 & 8.5 & 4 & \begin{tabular}{|l|}
8.5 \\
\end{tabular} & 2 & 4.3 & 47 & 100 & 4,02 \\
\hline$X_{2.2}$ & 17 & 36,2 & 21 & 44.7 & 2 & 4.3 & 7 & \begin{tabular}{|l|l}
14.9 \\
\end{tabular} & - & - & 47 & 100 & 4,02 \\
\hline$X_{2.3}$ & 17 & 36.2 & 18 & 38.3 & 4 & 8.5 & 7 & \begin{tabular}{|l|l}
14.9 \\
\end{tabular} & 1 & 2,1 & 47 & 100 & 3,91 \\
\hline$X_{1.4}$ & 18 & 38.3 & 19 & 40.4 & 3 & 6.4 & 7 & 14.9 & - & - & 47 & 100 & 4,02 \\
\hline $\mathrm{X}_{2.5}$ & 18 & 38.3 & 20 & 42.6 & 2 & 4.3 & 7 & 14.9 & - & - & 47 & 100 & 4,04 \\
\hline & & & & \multicolumn{9}{|c|}{ ta- } & 4,00 \\
\hline
\end{tabular}

Sumber : Data diolah

Hasil analisis pada Tabel 2 tentang jawaban responden tentang variabel pendidikan dan pelatihan yang diukur melalui 5 pernyataan. dengan nilai rata-rata sebesar 4,00\% menunujkan bahwa variabel ini mampu dijelaskan dengan baik oleh pernyataan-pernyataan diatas. Pernyataan yang relatif lebiih baik dalam menjelaskan variabel ini adalah pernyataan pertama $\left(X_{1 \cdot 5}\right)$, yaitu program pelatihan yang diikuti menambah wawasan bendahara.

\section{Distribusi Frekuensi Jawaban Responden Tentang Implementasi SIMDA}

Berikut ini adalah deskripsi jawaban responden mengenai pencarian variabel implementasi SIMDA:

Tabel 3

Rekapitulasi Distribusi Frekuensi Variabel Implementasi SIMDA

\begin{tabular}{|c|c|c|c|c|c|c|c|c|c|c|c|c|c|}
\hline \multirow{3}{*}{ Item } & \multicolumn{12}{|c|}{ Frekuensi Jawaban } & \multirow{3}{*}{$\frac{\text { Rata-rata }}{\%}$} \\
\hline & \multirow{2}{*}{$\begin{array}{c}5 \\
\text { SS }\end{array}$} & \multirow{2}{*}{$\%$} & 4 & \multirow{2}{*}{$\%$} & 3 & \multirow{2}{*}{$\%$} & \multirow{2}{*}{$\frac{2}{T S}$} & \multirow{2}{*}{$\%$} & \multirow{2}{*}{$\frac{1}{\text { STS }}$} & \multirow{2}{*}{$\%$} & \multicolumn{2}{|c|}{ Total } & \\
\hline & & & $\mathbf{S}$ & & $\mathbf{N}$ & & & & & & $F$ & $\%$ & \\
\hline$X_{3.1}$ & 16 & 34,0 & 18 & 38,3 & 5 & 10.6 & 8 & 17.0 & - & - & 47 & 100 & 3,89 \\
\hline $\mathrm{X}_{3.2}$ & 12 & 25,5 & 25 & 53.2 & 2 & 4.3 & 8 & 17.0 & - & - & 47 & 100 & 3,87 \\
\hline $\mathrm{X}_{3.3}$ & 15 & 31.9 & 22 & 46.8 & 3 & 6.4 & 6 & 12.8 & 1 & 2,1 & 47 & 100 & 3,94 \\
\hline$X_{3.4}$ & 17 & 36.2 & 20 & 42.6 & 2 & 4.4 & 8 & 17.0 & - & - & 47 & 100 & 3,98 \\
\hline $\mathrm{X}_{3.5}$ & 17 & 36.2 & 21 & 44.7 & 2 & 4.3 & 7 & 14.9 & - & - & 47 & 100 & 4,02 \\
\hline $\mathrm{X}_{3.6}$ & 20 & 42.6 & 12 & 25.5 & 5 & 10.6 & 10 & 21.3 & - & - & 47 & 100 & 3,89 \\
\hline \multicolumn{13}{|c|}{ Rata-rata Implementasi SIMDA } & 3,93 \\
\hline
\end{tabular}

Sumber : Data diolah

Hasil analisis pada Tabel 3 tentang jawaban responden tentang variabel implementasi SIMDA yang diukur melalui 6 pernyataan. dengan nilai rata-rata sebesar 3,93\% menunujkan bahwa variabel ini mampu dijelaskan dengan baik oleh pernyataanpernyataan diatas. Pernyataan yang relatif lebiih baik dalam menjelaskan variabel ini adalah pernyataan pertama $\left(\mathrm{X}_{3.5}\right.$ dan $\left.\mathrm{X}_{3.6}\right)$, yaitu dengan Aplikasi SIMDA Keuangan maka Sistem 
Pengendalian Intern berjalan dengan baik dimulai dari Penganggaran, Penatausahaan sampai pada pelaporan dan Aplikasi SIMDA Keuangan mampu manghasilkan informasi dengan ketepatan atau tingkat kebenaran yang lebih baik bila dibandingkan dengan pengolahan data manual.

\section{Distribusi Frekuensi Jawaban Responden Tentang Laporan Pertanggungjawaban}

Berikut ini adalah deskripsi jawaban responden mengenai pencarian variabel ketepatan waktu penyampaian laporan pertanggungjawaban bendahara pengeluaran:

Tabel 4

Rekapitulasi Distribusi Frekuensi Variabel ketepatan waktu penyampaian laporan pertanggungjawaban bendahara pengeluaran

\begin{tabular}{|c|c|c|c|c|c|c|c|c|c|c|c|c|c|}
\hline \multirow{3}{*}{ Item } & \multicolumn{12}{|c|}{ Frekuensi Jawaban } & \multirow{3}{*}{$\begin{array}{c}\text { Rata-rata } \\
\%\end{array}$} \\
\hline & 5 & \multirow{2}{*}{$\%$} & 4 & \multirow{2}{*}{$\%$} & 3 & \multirow{2}{*}{$\%$} & 2 & \multirow{2}{*}{$\%$} & 1 & & \multicolumn{2}{|c|}{ Total } & \\
\hline & SS & & $\mathbf{S}$ & & $\mathbf{N}$ & & TS & & STS & $\%$ & $F$ & $\%$ & \\
\hline$Y_{1.1}$ & 13 & 27,7 & 23 & 48,9 & 3 & 6.4 & 7 & 14.9 & - & - & 47 & 100 & 3,85 \\
\hline$Y_{1.2}$ & 17 & 36,2 & 20 & 42.6 & 3 & 6.4 & 7 & 14.9 & - & - & 47 & 100 & 4,00 \\
\hline$Y_{1.3}$ & 17 & 36,2 & 22 & 46.8 & 1 & 2.1 & 7 & 14.9 & - & - & 47 & 100 & 4,04 \\
\hline$Y_{1.4}$ & 21 & 44.7 & 14 & 29.8 & 4 & 8.5 & 2 & 4.3 & - & - & 47 & 100 & 3,98 \\
\hline$Y_{1.5}$ & 19 & 40.4 & 18 & 38.3 & 3 & 6.4 & 7 & 14.9 & - & - & 47 & 100 & 4,04 \\
\hline$Y_{1.6}$ & 14 & 29.8 & 24 & 51.1 & 2 & 4.3 & 7 & 14.9 & - & - & 47 & 100 & 3,96 \\
\hline$Y_{1.7}$ & 14 & 29.8 & 22 & 46.8 & 3 & 6.4 & 8 & 17.0 & - & - & 47 & 100 & 3.89 \\
\hline$Y_{1.8}$ & 17 & 26.2 & 19 & 40.4 & 4 & 8.5 & 7 & 14.9 & - & - & 47 & 100 & 3.98 \\
\hline \multicolumn{13}{|c|}{ Rata-rata ketepatan waktu penyampaian laporan pertanggungjawaban bendahara pengeluaran } & 3,96 \\
\hline
\end{tabular}

Sumber : Data diolah

Hasil analisis pada Tabel 4 tentang jawaban responden tentang variabel ketepatan waktu penyampaian laporan pertanggungjawaban bendahara pengeluaran yang diukur melalui 6 pernyataan. dengan nilai rata-rata sebesar 3,96\% menunujkan bahwa variabel ini mampu dijelaskan dengan baik oleh pernyataan-pernyataan diatas. Pernyataan yang relatif lebiih baik dalam menjelaskan variabel ini adalah pernyataan ketiga $\left(Y_{1.3}\right.$ dan $\left.X_{3 \cdot 6}\right)$, yaitu dengan bagaimana meningkatkan kualitas laporan administrasi dan fungsional yang menjadi tanggung jawab saya.

\section{Analisis Regresi Berganda}

Berikut ini adalah hasil pengujian dengan menggunakan analisis regresi berganda dengan menggunakan bantuan software SPSS (Statistikal Package for Social Science) versi 21.0. seperti yang terlihat pada Tabel 5 dibawah ini. 
Tabel 5

Hasil Analisis Regresi

\begin{tabular}{|l|c|c|c|c|}
\hline \multicolumn{1}{|c|}{ Variabel } & $\begin{array}{c}\text { Standardized } \\
\text { Coefficients }\end{array}$ & t hitung & Sig & Keterangan \\
\hline Constant & 2.564 & \multicolumn{5}{|l|}{} \\
\hline Kompetensi SDM & 0.585 & 1.581 & 0.086 & Tidak Signifikan \\
\hline Pendidikan dan Pelatihan & 0.619 & 3.955 & 0.000 & Signifikan \\
\hline Implemendasi SIMDA Keuangan & 0.413 & 2.038 & 0.048 & Signifikan \\
\hline R Square & 0.903 & \\
\hline Ajusted R Square & 0.896 \\
\hline t table & 1.683 \\
\hline Ftabel & 2.838 \\
\hline
\end{tabular}

Sumber : Data diolah

Dari data diatas menunjukan bahwa persamaan regresi dalam penelitian ini adalah sebagai berikut:

$$
Y=2.564+0.585 X_{1}+0.619 X_{2}+0.413 X_{3}+\varepsilon
$$

\section{Pengujian Hipotesis}

\section{Pengujian hipotesa pertama}

Adapun pengujian hipotesis dalam kajian ini dilakukan dengan asumsi sebagai berikut; $H_{a}$ diterima jika $t$ hitung $>t$ tabel, dengan kata lain ada pengaruh variabel independen terhadap penyajian laporan pertanggungjawaban bandahara pengeluaran dan $\mathrm{H}_{0}$ diterima jika $t_{\text {hitung }}<\mathrm{t}_{\text {tabel}}$, dengan kata lain variabel independen tidak mempengaruhi pengunaan informasi keuangan daerah.

Berdasarkan hasil analisis ditemukan bahwa variabel kompetensi SDM daerah terbukti tidak berpengaruh signifikan penyajian laporan pertanggungjawaban bandahara pengeluaran. Hal ini ditunjukan dengan besarnya nilai $t_{\text {hitung }}$ sebesar 1.581 sedangkan $t_{\text {tabel }}$ 1.683 sehingga $t_{\text {hitung }}<t_{\text {tabel }}(1.581<1.683)$ dengan nilai koefisien regresi adalah sebesar 0.086. Hasil pengujian ini menunjukan bahwa hipotesis penelitian pertama ditolak.

\section{Pengujian hipotesis kedua}

Berdasarkan hasil analisis ditemukan bahwa pendidikan dan pelatihan berpengaruh secara signifikan dan positif terhadap penyajian laporan pertanggungjawaban bandahara pengeluaran. Hal ini ditunjukan dengan besarnya nilai $t_{\text {hitung }}$ sebesar 3.955 sedangkan $t_{\text {tabel }}$ 
1.683 sehingga $t_{\text {hitung }}>t_{\text {tabel }}(3.955>1.683)$ dengan nilai koefisien regresi adalah sebesar 0.162. Hasil pengujian ini menunjukan bahwa hipotesis penelitian kedua diterima.

\section{Pengujian hipotesis ketiga}

Berdasarkan hasil analisis ditemukan bahwa implementasi berpengaruh secara signifikan dan positif terhadap penyajian laporan pertanggungjawaban bandahara pengeluaran. Hal ini ditunjukan dengan besarnya nilai $t_{\text {hitung }}$ sebesar 2.038 sedangkan $t_{\text {tabel }}$ 1.683 sehingga $t_{\text {hitung }}>t_{\text {tabel }}(2.038>1.683)$ dengan nilai koefisien regresi adalah sebesar 0.000. Hasil pengujian ini menunjukan bahwa hipotesis penelitian ketiga diterima.

\section{Pengujian hipotesis keempat}

Berdasarkan hasil analisis ditemukan bahwa kompetensi SDM, pendidikan dan pelatihan dan implementasi SIMDA secara bersama-sama (simultan) berpengaruh positif dan signifikan terhadap penyajian laporan pertanggungjawaban bandahara pengeluaran. Hal ini ditunjukan dengan besarnya nilai $f_{\text {hitung }}$ sebesar 133.454 sedangkan $F_{\text {tabel }} 2.838$ sehingga $F_{\text {hitung }}>F_{\text {tabel }}(133.454>2.838)$ dengan nilai koefisien regresi adalah sebesar -0.013 . Hasil pengujian ini menunjukan bahwa hipotesis penelitian keempat diterima.

\section{Pembahasan}

Hasil pengujian hipotesis terbukti kualitas kompetensi SDM tidak berpengaruh signifikan terhadap penyajian laporan pertanggungjawaban bendahara pengeluaran. Hal ini dapat di justifikasi kualitas kompetensi SDM tidak dapat meningkatkan penyajian laporan pertanggungjawaban bendahara pengeluaran. Artinya dengan kompetensi SDM yang baik maka belum mampu menjamin penyajian laporan pertanggungjawaban bendahara pengeluaran juga akan baik.

Hasil penelitian diatas bertolak belakang dengan hasil penelitian Nurmala (2019) membuktikan bahwa kompetensi SDM secara simultan berpengaruh terhadap ketepatan waktu penyampaian laporan pertanggungjawaban Pemerintah Daerah Kabupaten Aceh Tamiang. Begitu pula Handayani, Iskandar Muda, Si, \& Ak (2017) membuktikan bahwa secara simultan dan parsial variabel sumber daya berpengaruh terhadap ketepatan waktu laporan keuangan pemerintah daerah di Sumatera Utara. Kompetensi SDM yang dimiliki 
akan mendorong seorang bendahara pengeluaran untuk sungguh-sungguh bekerja sesuai dengan tugas pokok dan fungsinya. keuangan pemerintah daerah.

Hasil penelitian ini dapat dijelaskan bahwa ketepatan waktu penyampaian laporan pertanggung jawaban bendahara pengeluaran di Pemerintah Kabupaten Sarmi dalam hal kompetensi SDM antara lain dengan Tugas Pokok dan Fungsi, kemampuan, pengetahuan, sikap dan nilai. Jika kesemuanya didapat maka bendahara pengeluaran dengan kompetensi SDM-nya akan maksimal dalam bekerja dan dapat menyelesaikan laporan pertanggung jawabannya dengan baik sesuai dengan waktu yang telah ditentukan.

Hasil pengujian variabel pendidikan dan pelatihan terhadap variable ketepatan waktu penyampaian laporan pertanggung jawaban bendahara pengeluaran menggunakan uji statistik t dan diperoleh hasil tingkat signifikansi variabel pelatihan sebesar $0,000<\alpha(0,05)$ dan koefisien regresi 0,619 . Hal ini menunjukkan bahwa variabel pendidikan dan pelatihan secara parsial berpengaruh positif signifikan terhadap ketepatan waktu penyampaian laporan pertanggung jawaban bendahara pengeluaran.

Hasil penelitian ini sejalan dengan penelitian Wasasih et al. (2016) menyatakan bahwa pendidikan berpengaruh positif signifikan pada kinerja bendahara organisasi perangkat daerah (OPD) Kabupaten Sarmi. Begitu juga dengan penelitianNurmala (2019) yang menyatakan bahwa intensitas pelatihan penatausahaan berpengaruh secara simultan dan parsial terhadap ketepatan waktu penyampaian laporan pertanggung jawaban Pemerintah Daerah Kabupaten Aceh Tamiang. Hasil penelitian ini sejalan dengan hasil penelitian Achmad, Hasyim, Dahlan, \& Aulia (2015) menyatakan bahwa pelatihan secara simultan berpengaruh terhadap kualitas pertanggungjawaban Laporan Keuangan dekonsentrasi pada Satuan Kerja Pemerintah Aceh. Hasil penelitian ini juga terdukung dengan hasil penelitianHandayani et al. (2017) menyatakan bahwa intensitas pelatihan secara signifikan berpengaruh terhadap ketepatan waktu laporan keuangan pemerintah daerah di Sumatera Utara.

Hasil penelitian ini dapat dijelaskan bahwa pendidikan dan pelatihan yang diikuti oleh bendahara pengeluaran di Pemerintah Kabupaten Sarmi seharusnya dapat meningkatkan 
kualitas dan cara bendahara pengeluaran tersebut menyelesaikan pekerjaannya serta untuk mempertanggungjawab hasil kerjanya. Pendidikan dan pelatihan sangat berguna untuk mengatahui cara termudah dalam menyelesaikan pekerjaan sehari-hari, dalam hal ini yang berhubungan dengan laporan pertanggung jawaban bendahara pengeluaran.

Hal-hal yang seharusnya di lakukan oleh bendahara pengeluaran di di lingkungan Pemerintah Kabupaten Sarmi dapat meningkatkan/mempercepat ketepatan waktu penyampaian laporan pertanggung jawaban bendahara pengeluaran dalam hal pendidikan dan pelatihan antara lain dengan peluang mengikuti program kursus, manfaat yang di peroleh dalam mengikuti kursus, ketersedian informasi program, pengembangan lain. Jika semua dilaksanakan dalam pendidikan dan pelatihan maka bendahara pengeluaran dapat dengan mudah menyampaikan laporan pertanggung jawaban tepat waktu.

Hasil pengujian menunjukan pengaruh variabel implementasi Sistem Informasi Manajemen Daerah terhadap variabel ketepatan waktu penyampaian laporan pertanggung jawaban bendahara pengeluaran menggunakan uji statistik t. Hasil analisis menunjukkan bahwa variabel implementasi Sistem Informasi Manajemen Daerah secara parsial berpengaruh positif signifikan terhadap ketepatan waktu penyampaian laporan pertanggung jawaban bendahara pengeluaran.

Hasil penelitian ini sejalan dengan dengan hasil penelitian Loudon (2008) yang menyatakan system informasi dibangun oleh manajer untuk melayani kepentingan perusahaan. Pada saat bersamaan, organisasi harus waspada dan terbuka terhadap pengaruh system informasi untuk mendapatkan manfaat dari teknologi baru. Sistem informasi menjadi vital untuk menjalankan bisnis harian serta mencapai tujuan bisnis dan tujuan strategi. Hasil penelitiaan ini terdukung dengan hasil penelitianSupartoy (2009.) menyatakan bahwa apliksi Sistem Informasi Manajemen Daerah merupakan suatu program yang dikembangkan dengan menggunakan database. Sedangkan Database menurut Laudon (2007) merupakan sekumpulan data organisasi untuk melayani banyak aplikasi secara efisien dengan memusatkan dan mengendalikan data. Trihapsoro \& Setiawati (2015) 
menyimpulkan bahwa pemanfaatan teknologi informasi berpengaruh signifikan terhadap kinerja pemerintah daerah.

Implementasi Sistem Informasi Manajemen Daerah merupakan salah satu faktor terpenting dalam bekerja terutama buat bendahara pengeluaran di Pemerintah Kabupaten Sarmi dalam penggunaan Sistem Informasi Manajemen Daerah dapat menghemat waktu dan dapat meminimalisir kesalahan dalam bekerja khususnya dalam pembuatan laporan pertanggung jawaban serta merupakan salah satu keharusan menggunakan Sistem Informasi Manajemen Daerah dalam menyelesaikan pekerjaan sebagai seorang bendahara pengeluaran.

Ketepatan waktu penyampaian laporan pertanggung jawaban bendahara pengeluaran dalam hal implementasi Sistem Informasi Manajemen Daerah antara lain dengan diukur berdasarkan persepsi responden tentang manfaat adanya sistem informasi manajemen daerah bagi bendahara, maupun PPKD SKPD. Jika semua dilaksanakan dalam implementasi Sistem Informasi Manajemen Daerah maka bendahara pengeluaran dapat dengan mudah menyampaikan laporan pertanggung jawaban sesuai dengan waktu yang telah ditetapkan.

Hipotesis keempat atau yang terakhir dalam penelitian ini menyatakan bahwa “Kompetensi sumber daya manusia (KSDM), pendidikan dan pelatihan serta implementasi SIMDA secara bersama-sama (simultan) berpengaruh terhadap penyajian laporan pertanggungjawaban bendahara pengeluaran". bahwa Kompetensi sumber daya manusia (KSDM), pendidikan dan pelatihan serta implementasi SIMDA secara bersama-sama (simultan) berpengaruh terhadap penyajian laporan pertanggungjawaban bendahara pengeluaran pemerintah Kabupaten Sarmi. 


\section{SIMPULAN}

Penelitian ini menarik beberapa kesimpulan: factor kompetensi SDM tidak berpengaruh signifikan terhadap penyajian laporan pertanggungjawaban bandahara pengeluaran pemerintah Kabupaten Sarmi. Sebaliknya factor pendidikan dan pelatihan berpengaruh positif dan signifikan. Demikian juga factor Implementasi SIMDA berpengaruh positif dan signifikan. Ketiga variable secara bersama-sama (simultan) berpengaruh positif dan signifikan terhadap penyajian laporan pertanggungjawaban bandahara pengeluaran pemerintah Kabupaten Sarmi.

Studi ini menyarankan kepada peneliti lain untuk menambah variabel lain untuk penelitian serupa, seperti reward dan stres/tekanan kerja. Selain itu penambahan responden dan penggunaan teknik pengumpulan data, selain yang dipakai dalam studi ini akan sangat bermanfaat.

Studi ini memiliki keterbatasan seperti pada jumlah sampel dan wawancara langsung. Saat wawancara dapat terjadi intervensi peneliti yang dapat mempengaruhi responden.

\section{DAFTAR PUSTAKA}

Achmad, A., Hasyim, S., Dahlan, B., \& Aulia, D. N. (2015). Modeling of urban growth in tsunami-prone city using logistic regression: Analysis of Banda Aceh, Indonesia. Applied Geography, 62, 237-246.

Breitenfellner, B., \& Wagner, N. (2010). Government intervention in response to the subprime financial crisis: The good into the pot, the bad into the crop. International Review of Financial Analysis, 19(4), 289-297.

Brower, R. S., Abolafia, M. Y., \& Carr, J. B. (2000). On improving qualitative methods in public administration research. Administration \& Society, 32(4), 363-397.

Dessler, G. (2011). Fundamentals of human resource management. Pearson Higher Ed.

Dharma, S. (2015). Peningkatan Kinerja Keuangan Daerah Dalam Konteks Pemanfaatan Sistem Informasi Manajemen Daerah (SIMDA) Pada SKPD Kabupaten Buton Utara. Fakultas Ekonomi UNISSULA.

Hadiputro, E. K. (2015). PENGARUH KOMPETENSI SUMBER DAYA MANUSIA DAN PENERAPAN SISTEM AKUNTANSI INSTANSI TERHADAP KUALITAS LAPORAN KEUANGAN (Survei padaBadan Geologi, Kementerian Energi Sumber Daya Mineral). Universitas Widyatama.

Handayani, C. H., Iskandar Muda, S. E., Si, M., \& Ak, C. A. (2017). Analisis Faktor-Faktor yang Mempengaruhi Serapan Anggaran SKPD di Provinsi Sumatera Utara Tahun 20142015 dengan SiLPA sebagai Variabel Moderating. Jurnal SNA. Universitas Sumatera 
Utara.

Hariandja, M. T. E. (2002). Manajemen sumber daya manusia. Grasindo.

Hasbullah, H. (2008). Pendidikan Konservasi untuk Orang Dewasa. Tropika.

Jensen, M. C., \& Meckling, W. H. (1979). Theory of the firm: Managerial behavior, agency costs, and ownership structure. In Economics social institutions (pp. 163-231). Springer.

Jogiyanto, H. M. (2008). Metodologi penelitian sistem informasi. Yogyakarta: Penerbit Andi.

Kennedy, H. P., Shannon, M. T., Chuahorm, U., \& Kravetz, M. K. (2004). The landscape of caring for women: a narrative study of midwifery practice. Journal of Midwifery \& Women's Health, 49(1), 14-23.

Laudon, K. C. (2007a). dan Jane P. Laudon.

Laudon, K. C. (2007b). Management information systems: Managing the digital firm. Pearson Education India.

Lupia, A., \& McCubbins, M. D. (2000). Representation or abdication? How citizens use institutions to help delegation succeed. European Journal of Political Research, 37(3), 291-307.

Machmud, R. (2013). Peranan penerapan sistem informasi manajemen terhadap efektivitas kerja pagawai lembaga pemasyarakatan narkotika (lapastika) bollangi kabupaten gowa. Jurnal Capacity STIE AMKOP Makassar, 9(3), 409-421.

Madukala, M. M., Nasrul, N., \& Mahrani, S. W. (2018). PENGARUH PENGGUNAAN SISTEM INFORMASI MANAJEMEN DAERAH (SIMDA) KEUANGAN BERBASIS AKRUAL DAN KEPUASAN KERJA TERHADAP KINERJA PEGAWAI. Jurnal Manajemen, Bisnis Dan Organisasi (JUMBO), 2(2), 1-13.

Magner, N., \& Johnson, G. G. (1995). MUNICIPAL OFFICIALS'REACTIONS TO JUSTICE IN BUDGETARY RESOURCE ALLOCATION. Public Administration Quarterly, 439-456.

Mangkunegara, A. P., \& Prabu, A. (2003). Perencanaan dan pengembangan sumber daya manusia. Bandung: Refika Aditama.

Meliani, E. N. (2018). Pengaruh Kompetensi Dan Budaya Organisasi Terhadap Komitmen Afektif Dan Dampaknya Pada Kinerja Pegawai"(Studi Kasus Pada Cabang Pelayanan Pendapatan (CPPD) Wilayah Kota I Bandung Pajajaran). Perpustakaan Pascasarjana.

Meng, Q.-J., Logunova, L., Maywood, E. S., Gallego, M., Lebiecki, J., Brown, T. M., ... Piggins, H. D. (2008). Setting clock speed in mammals: the CK1ع tau mutation in mice accelerates circadian pacemakers by selectively destabilizing PERIOD proteins. Neuron, 58(1), 78-88.

Moekijat, D. (2002). Manajemen Sumber Daya Manusia. Pionir Jaya, Bandung.

Nilawati, I. (2009). Kajian Keterlambatan Laporan Pertanggungjawaban Pengeluaran Satuan Kerja Perangkat Daerah (SKPD) di Kabupaten Lampung Tengah Tahun 2008. Retrieved Sept, 20, 2014.

Nilsson, M., Sagerfors, J., Buffam, I., Laudon, H., Eriksson, T., Grelle, A., ... Lindroth, A. (2008). Contemporary carbon accumulation in a boreal oligotrophic minerogenic mire-a significant sink after accounting for all C-fluxes. Global Change Biology, 14(10), 23172332.

Nur'aini, S., Hasan, A., \& Al Azhar, A. (2016). Pengaruh Pelayanan, Produktivitas, Kompensasi, Dan Sumber Daya Manusia Terhadap Kinerja Pdam Tirta Kampar-Kota 
Bangkinang. Riau University.

Nurmala, H. (2019). Pengaruh kecerdasan emosional dan kecerdasan spiritual terhadap produktivitas kerja: Studi pada karyawan PT Pos Indonesia Bandung. UIN Sunan Gunung Djati Bandung.

Permana, D. Y., \& Rahardjo, S. N. (2013). Pengaruh Pertumbuhan Ekonomi, Pendapatan Asli Daerah, Dana Alokasi Umum, dan Dana Alokasi Khusus terhadap Pengalokasian Anggaran Belanja Modal. Fakultas Ekonomika dan Bisnis.

Rahmatiah, D. R. (2016). Analisis penatausahaan dan penyusunan laporan pertanggungjawaban bendahara serta penyampaiannya pada dinas pendapatan pengelola keuangan dan aset daerah kabupaten bone bolango. Jurnal EMBA: Jurnal Riset Ekonomi, Manajemen, Bisnis Dan Akuntansi, 4(1).

Robbins, S. P. (n.d.). Judge.(2008) Perilaku Organisasi. Jakarta: Salemba Empat.

Safwan, N., \& Abdullah, S. (2014). Pengaruh kompetensi dan motivasi terhadap kinerja pengelolaan keuangan daerah pada Pemerintah Daerah Kabupaten Pidie Jaya. Jurnal Akuntansi ISSN, 2302, 164.

Salle, A., Iek, M., \& Hafizrianda, Y. (2015). Kajian pengelolaan dana otonomi khusus untuk peningkatan pelayanan masyarakat asli Papua. (Akbar Silo, Ed.) (Kedua). Jayapura: $\begin{array}{llll}\text { Uncen Press. } & \text { Retrieved }\end{array}$ http://repository.mkduncen.ac.id/index.php?p=fstream\&fid=8\&bid=7

Schipper, K. (1989). Earnings management. Accounting Horizons, 3(4), 91.

Siagian, S. P. (2011). Manajemen Sumber Daya Manusia (Human Resource Management). Jakarta: PT. Bumi Aksara.

Soeharto, E. (2005). Analisis Kebijakan Publik Panduan Praktis Mengkaji Masalah dan Kebijakan Sosial. Alfa Beta, Bandung.

Sugiyono, P. (2005). Memahami penelitian kualitatif. Bandung: Alfabeta.

Supartoyo, G. (n.d.). Suantika and Djadja 2009. Peta Kawasan Rawan Bencana Gempabumi Pulai Bali.

Trihapsoro, A., \& Setiawati, E. (2015). Pengaruh Kualitas Sumber Daya Manusia, Pemanfaatan Teknologi Informasi Dan Sistem Pengendalian Intern Pemerintah Terhadap Kinerja Pemerintah Daerah (Studi Pada Satuan Kerja Perangkat Daerah Kabupaten Boyolali). Universitas Muhammadiyah Surakarta.

Varejão, A. S. P., Meek, M. F., Ferreira, A. J. A., Patrício, J. A. B., \& Cabrita, A. M. S. (2001). Functional evaluation of peripheral nerve regeneration in the rat: walking track analysis. Journal of Neuroscience Methods, 108(1), 1-9.

Wahyuni, E. (2019). Pengaruh Retribusi Daerah Dan Dana Alokasi Umum Terhadap Belanja Modal (Survei Pada Kabupaten Dan Kota Di Provinsi Jawa Barat). Universitas Komputer Indonesia.

Wasasih, N. M., Yadnyana, I. K., \& Rasmini, N. K. (2016). Pengaruh Pendidikan Pada Kinerja Bendahara Dengan Pelatihan Dan Motivasi Sebagai Pemoderasi. E-Jurnal Ekonomi Dan Bisnis Universitas Udayana.

Wedemeyer, G. A., \& Ross, A. J. (1973). Nutritional factors in the biochemical pathology of corynebacterial kidney disease in the coho salmon (Oncorhynchus kisutch). Journal of the Fisheries Board of Canada, 30(2), 296-298.

Wibowo, P. D. (2013). Manajemen Kinerja. edisi ketiga. Jakarta: Rajawali Pers. 
Wokas, H., Poputra, A. T., \& Sugeha, A. (2015). Penatausahaan dan Penyusunan Laporan Pertanggungjawaban Bendahara Serta Penyampaiannya pada Dinas Pendapatan Pengelola Keuangan dan Aset Daerah Kabupaten Bolaang Mongondow. Jurnal Riset Ekonomi, Manajemen, Bisnis Dan Akuntansi, 3(1), 2475. 